restricting the retention of basic metabolites in the tissue. Serotonin metabolism was reviewed by Dr. S. Udenfriend (Bethesda) and histamine by Dr. G. B. West (London).

The proceedings of the Symposium will be appearing shortly under the title "Metabolism of Nervous Tissue", edited by Dr. D. Richter and published by the Pergamon Press, London.

\section{SOCIETY OF LEATHER TRADES' CHEMISTS}

\section{ANNUAL CONFERENCE}

$\mathrm{T}$ HE annual conference of the Society of Leather Trades' Chemists was held in the University of Leeds during September 21-22, the chair being occupied by the president, Dr. R. G. Mitton. The morning session of the first day was opened with a paper by Dr. G. H. Green on the mechanism of liming and bating. The main object of bating is to prevent adherence of leather fibres on drying, and evidence was put forward which leads to the following scheme :

intact collagen $\stackrel{\text { lime }}{\longrightarrow}$ progelatin $\stackrel{\text { heat }}{\rightarrow}$ gelatin $\stackrel{\text { trypsin }}{\rightarrow}$ peptides of low molecular weight

Progelatin consists of filamented collagen fibres produced on the newly formed collagen fibre-surface after liming or other swelling treatment, which, by its polar nature, acts as a glue when the fibres are dried. Removal of this progelatin restores the isoelectric point of the collagen, previously lowered to about $p \mathrm{H} .5 .0$ by alkali hydrolysis, and progelatin causes what is technically termed 'falling' and develops air-permeability and some silliness of the grain surface of the pelt. Re-liming a skin after bating causes a serious loss of substance by progelatin formation, due to the bating enzymes assisting the action of the lime.

The tanning characteristics of aliphatic aldehydeketone resins were then discussed by $J$. R. B. Hastings and Dr. T. White. A resin tannage was described in which the hide is first impregnated with a condensate prepared by the alkali-catalysed reaction between an aliphatic aldehyde and ketone, which is afterwards resinified in situ by further alkali treatment. The leather can contain up to 20 per cent of resin with an increase in shrinkage temperature of $14 \mathrm{deg}$. C. The condensates can be converted into water-soluble products by treatment with sulphites or bisulphites and employed by conventional tanning methods. The role of the sulphonate group in the solubilized products was discussed and further compared with analogous sulphonated tanning materials. The aldehyde-ketone condensates were thought to have potential value if used with other tanning materials.

The last contribution to the morning session was a paper by Prof. D. Burton and Dr. R. Reed on some further electron-microscope researches, in which the structural changes in tanned collagen fibrils during shrinkage in hot water were described. First, the fibrils swelled either at certain regions along their length or at their ends. The bands across the fibrils became fainter in the swollen regions and, significantly, became much closer together. At the same time the swollen portions flattened and assumed a peculiar spiral form. 'This initial swelling was usually observed at a temperature below that of marro- shrinkage-that is, below that of a strip of leather as determined in the usual apparatus. Moreover, the fibrils in any particular sample of leather did not all swell and shrink at the same rate. On raising the temperature, the swollen fibrils broke across to form short stubby structures, which on prolonged heating were reduced to ill-defined masses of glue-like material. These changes appeared to take place with all the leathers so far examined, but were best illustrated in the case of chrome and oil-tanned leathers where the fibrils were not obscured by the presence of amorphous material such as vegetable tannin. On the basis of these results, suggestions were put forward for the structure of the native collagen fibril, its stabilization by tannage and its shrinkage by hot water.

The afternoon session was devoted to the delivery of the seventh Procter Memorial Lecture by Dr. G. W. Kenner, who selected for his subject the present and future scope of peptide synthesis. During recent years, great advances have been made in the analytical and structural chemistry of proteins and the question must be asked whether synthesis will keep pace. No deep and rapid incursion into this field should be expected, but progress in two directions is discernible. Oligopeptides containing some ten amino-acid residues arranged in a definite sequence can now be constructed from most, if not all, of the amino-acids which occur in proteins; the chief interest in such compounds has lain in their relation to hormones and antibiotics, but they may also prove useful as models in studies of protein reactions. Many polypeptides have been synthesized from single amino-acids, and the possibility of repeating many times a given short sequence is now apparent.

For building oligopeptides of defined structure, one still relies fundamentally on the approach made by M. Bergmann-namely, protection of the terminal amino-group of an amino-acid or peptide, while the terminal carboxyl group is condensed with the aminogroup of another section of the peptide chain. However, the actual range of methods is now much greater than that which was available to Bergmann. In addition to Bergmann's carbobenzoxy-protecting group, one now has the tosyl, phthaloyl and trityl groups-to name only the most important-and in addition to the azide method of condensation, there are those methods relying on various mixed anhydrides, cyanomethyl esters, thiolesters, derivatives of trivalent phosphorus, and carbodi-imides. The power of these methods has been amply demonstrated in the syntheses of oxytocin and related compounds by du Vigneaud and his colleagues as well as by other groups of workers.

Polypeptides have been synthesized from the $\mathrm{N}$-carboxyanhydrides of amino-acids; but this method is not applicable to the production of material containing more than one amino-acid and having a defined structure. For this purpose some of the methods used in the synthesis of oligopeptides can be adapted ; but there are many problems in securing reasonable yields of material with a high molecular weight. Nevertheless, progress along these lines can be confidently expected.

The remainder of the afternoon of the first day was occupied by the annual general meeting of the Society.

The morning of the second day of the conference was opened with a paper by N. L. Holmes and H. G. Wollenberg on investigations into the rate of tannage of sole leather. In this work, which was devoted to 
a study of the effect of temperature on the rate of tanning of sole leather, it was found generally that the total uptake of tannin increased with increase in temperature, as also did the rate of uptake, the temperature-levels used being $8^{\circ}, 18^{\circ}, 28^{\circ}$ and $38^{\circ} \mathrm{C}$. This was followed by the concluding paper of the meeting, by J. M. Harrison and T. Turner, on some experiments on the impregnation of sole leathers, in which were described some laboratory-scale experiments on the use of polymeric materials to improve abrasion resistance and water repellence of sole leather. The factors associated with emulsion impregnation and solvent impregnations were discussed. Many of the monomers, which on polymerization would give the type of elastomer required, are very volatile, and this has presented one of the difficulties. One method of in situ polymerization has been developed which gives a leather of improved properties.

\section{LIBRARY PROBLEMS IN GREAT BRITAIN}

T $T$ is difficult to discern a common thread in the 1 papers presented at this year's conference of the Library Association, held in Folkestone during September 18-21, though several of them stressed the importance of an adequate library system in relation to technological education and indeed to further education and the dissemination of information generally. In his paper on libraries in colleges of technology and further education, Mr. L. L. Ardern attacked the Government's failure to implement plans for an adequate national library service, at any rate for science and technology, and he was fully supported by Dr. G. Chandler and, at least by implication, by Mr. O. S. Tomlinson, who, reviewing post-war influences on librarianship, referred to the indifference of the teaching world, except in the universities and grammar schools, to the educational value of books.

Mr. Ardern began with a most interesting review of the early development of technical college libraries down to the official admission of their vital importance, which he welcomed, in the recent White Paper on Technical Education; but he showed convincingly how poor is the overall provision and how great is the need for some effective regional co-operation in each industrial area between the public libraries, the technical colleges and industrial libraries. Mr. Ardern remarked that we do not ask often enough how much duplication we can afford and suggested that this is a field where local co-operation would be particularly valuable, though the technical college library has to give priority to the subject fields of the departments it serves, and this limits the extent to which it can serve other fields.

Mr. Ardern fully recognized that the library is only a part of the technical college and that we cannot expect the part to be healthy, virile and progressive if the whole is not. He was clearly sceptical as to the Government's proposals for technical education providing us with colleges which are not over crowded, under-staffed and under-equipped. Or. G. Chandler, discussing present trends and future developments in large municipal libraries, did not mention the technical colleges, but in his reference to special libraries, to technical libraries and to patent libraries he was likewise concerned with the Govern- ment's fuilure to implement the recommendations of the Advisory Council on Scientific Policy. The rapid dissemination of scientific and technical information is probably, he said, from the national point of view the most vital library problem, and large public libraries will not be able to meet the varied specialist demands of to-day unless the Government gives them much greater preferential treatment than at the moment. The Government does not realize, he said, that large public libraries are, in effect, national institutions and that they serve an even more advanced section of society than either the technicai colleges or universities.

Dr. Chandler urged that libraries have as large a part to play in education as have schools and colleges, and that education is more than ever a pre-requisite of our survival in a fiercely competitive world. In this he and Mr. Ardern were fully supported by Mr. E. R. Lake in a paper on reading in the television age, as well as by the president of the Association, Mr. Edward Sydney, who concluded his presidential address by remarking that the public library service in any really democratic society is, and always will be, an essential instrument in enabling its citizens to live wisely, agreeably and well. Mr. Sydney devoted his address mainly to developments during the decade since the Second World War, stressing, like $\mathrm{Mr}$. Ardern, in his more limited field, the need for greater co-operation, for high standards in provision of books, of service and of staff; Mr. Sydney also gave a brief glance at the international field, which was surveyed in greater detail by Dr. H. Coblans in a paper entitled "International Librarianship-Some Problems and Implications". To the scientist the chief interest of Dr. Coblans's paper lies in his reference to the opportunities which bibliography, documentary reproduction and translation offer for international action. Commenting that, in spite of some improvement in co-operation between national services in certain subjects, the abstracting services as a whole deteriorate every year, becoming more expensive, less complete in coverage and more numerous, Dr. Coblans said that international agreement to co-operate along well-defined lines offers the only hope of solution. Chemical Abstracts, he remarked, in 1956 costs six times what it cost in 1955 . During the past few months Unesco has accepted some responsibility for defining the problems presented by the automatic printing of large numbers of references or index entries and the solution of items of knowledge on a given subject, and also for stimulating research and study for centres at various stages of library development.

Mr. D. J. Foskett, in a paper entitled "Science, Humanism and Libraries", maintained that science is much more than the accumulation of masses of data and that the failure to realize this is a major cause of misunderstanding and of breakdown in the communication of science. In the course of his work the scientist gains new knowledge and new ideas which are capable of inspiring him with emotions akin to those felt by the poet and the artist, and these have to be communicated in such a way that others also can appreciate their significance. Mr. Foskett thought that it is important to get into our libraries those works which deal with the specifically human side of science, such as the histories and biographies, and that one reason why scientists become so specialized in outlook is the mere mass of publication, some of a very low standard and much of it repetitious. He suggested that libraries should attempt to discourage 